\title{
A comparison of specific growth rates of periphytic diatoms of varying cell size under laboratory and field conditions
}

\author{
Soizic Morin $\cdot$ Michel Coste $\cdot$ François Delmas
}

Received: 4 January 2008/Revised: 5 June 2008/Accepted: 24 June 2008/Published online: 15 July 2008

(C) Springer Science+Business Media B.V. 2008

\begin{abstract}
Diatom species grown under non-limiting nutrient availability in multispecific biofilms were sampled from glass substrates immersed in the field and in experimental freshwater microcosms, and their growth responses were determined. The major species that developed on the substrates were common to both experiments and the specific growth rates $(k)$ ranged from 0.06 to 0.41 division day ${ }^{-1}$. An inverse relationship between $k$ and cell sizes was observed, which is in accordance with allometry results reported by several authors. Although found in lower amounts, the large, slow-growing species accounted significantly in total community biovolume, underlying their significance for ecological purposes. From growth characteristics data, life history strategies were drawn for the dominant species recorded, from small pioneer species to large taxa that are more favoured by high resource supply. Kinetic data measured in both laboratory and in situ experiments stressed that the difficulties to mimic the field in laboratory experiments may have a strong impact on growth kinetics.
\end{abstract}

Handling editor: J. Padisak

S. Morin $(\bowtie) \cdot$ M. Coste $\cdot$ F. Delmas

Cemagref, UR REBX, 50 Avenue de Verdun,

33612 Cestas cedex, France

e-mail: soizic.morin@bordeaux.cemagref.fr
Keywords Periphytic diatoms - Growth rates . Cell size $\cdot$ Life history strategies · Field study · Freshwater microcosms

\section{Introduction}

The structure of microalgal communities plays an important role in determining the trophic interactions within aquatic food webs (from autotrophic production to zooplankton feeding), and several models have been proposed to establish cell size/algal growth rate relationships in phytoplankton assemblages. The concept of relative specific growth rates was originally used for marine phytoplankton (Goldman, 1980) and applied by Bothwell $(1985,1989)$ to freshwater periphytic diatom communities. Surveys by Banse (1982), Tang (1995) and Kagami \& Urabe (2001), using cell biovolume as a measure of size, found a uniform distribution of phytoplankton biomass among logarithmically increasing size classes. These allometric studies led to the commonly accepted conclusion that big diatom species have longer cell cycles than smaller ones.

Benthic diatom communities, which are important primary producers in streams, are composed of a large number of species with various ecological preferences (Lange-Bertalot, 1979; Steinberg \& Schiefele, 1988; van Dam et al., 1994), which confer to these organisms a high relevance among biological 
indicators. Growth responses of freshwater diatoms are mainly used for determination of ecological optima (Baars, 1983; Suzuki \& Takahashi, 1995), for algal toxicity assays (Conway \& Williams, 1979; Schmitt-Jansen \& Altenburger, 2005) and for the evaluation of environmental conditions (Biggs, 1990; Admiraal et al., 2000). Species-specific studies of growth responses have already been performed on monocultures of diatoms; however, little can be said about their significance for natural multispecific populations. Extrapolating responses from one species of diatom to another, or even from species-byspecies studies, can therefore be misleading, due to interactive effects in the whole environment (Tilman, 1977; Tilman et al., 1981, 1986; van Donk \& Kilham, 1990; Wood \& Leatham, 1992; Descamps-Julien \& Gonzalez, 2005). Specific growth rates, which vary among species depending on individuals' sizes, may thus also be enhanced by enriching elements or reduced by competitive exclusion between organisms or contaminations with toxicants.

This study attempts to elucidate the relationships between the integrated metabolic parameter growth rate of many diatom species grown in multispecific cultures and their specific biovolume, with regards to life history strategies sensu Grime (1977). Here, we investigated the contributions of both laboratory and in situ relative specific growth rates.

\section{Materials and methods}

As part of a wider evaluation of periphyton in the industrial watershed of Decazeville (see Morin et al., 2008a), data for this study were collected from a site in the Riou-Mort stream, South West France $\left(44^{\circ} \mathrm{N} /\right.$ $2^{\circ} \mathrm{E}$ ), placed upstream of the metal discharge from a small tributary carrying seepage from a former zinc factory (Fig. 1). The growth rate experiments using artificial substrate samplers were carried out in March 2005 over a 20-day period. The survey was complemented with a laboratory assay conducted in March 2006, the experimental systems being inoculated with natural biofilm taken from the same site. Periphytic communities in both studies were composed of thin biofilms dominated by diatoms.

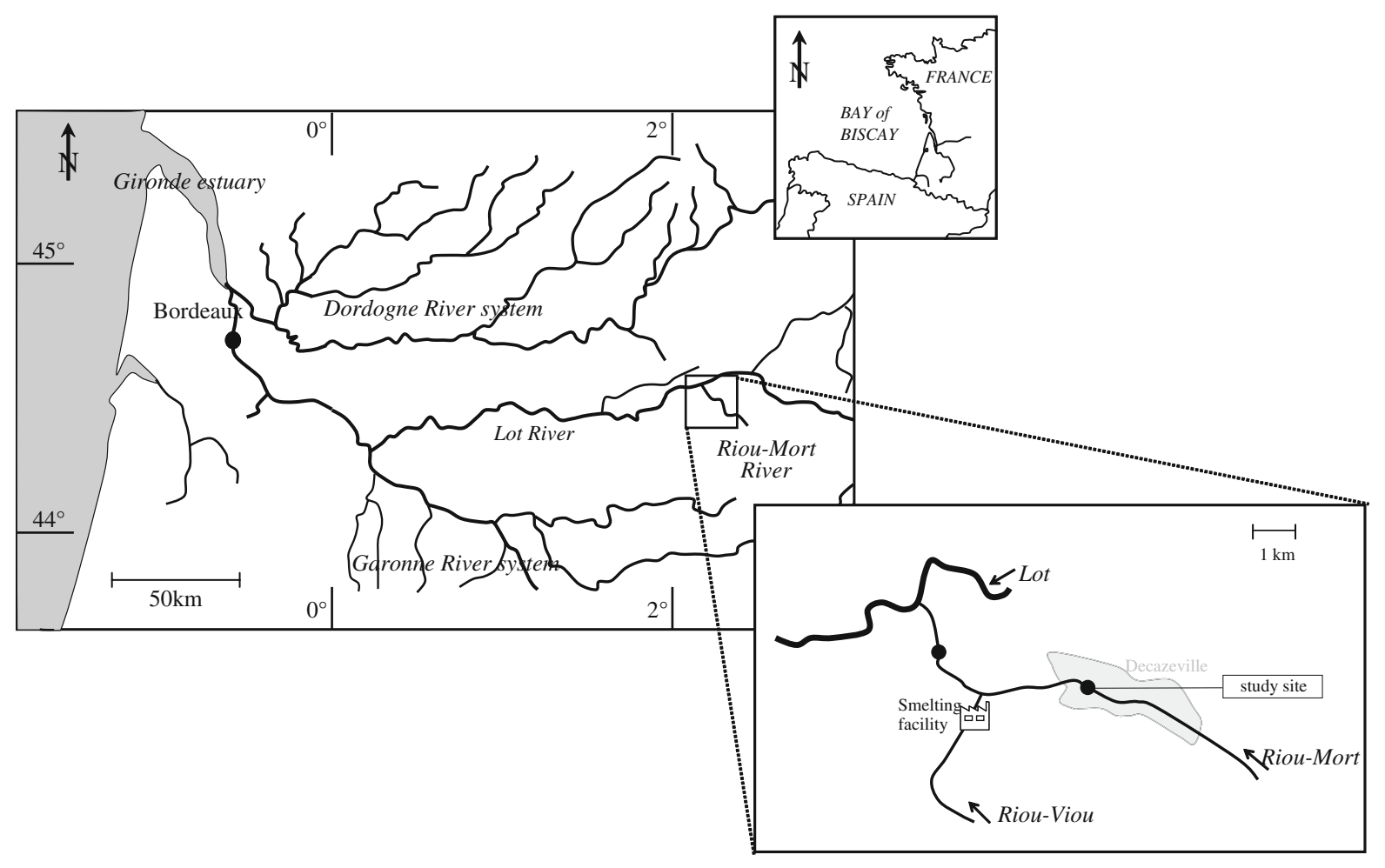

Fig. 1 Location of the study site 
Field sampling

Two caged, artificial samplers loaded with six vertically aligned glass slides (see Morin et al., 2007) were installed at each site for algal collection, at a depth of about $10 \mathrm{~cm}$ below the surface. Water velocity and light irradiance were standardized as closely as possible because of their potential influence on growth rates.

The samples (three replicate slides per sampling date) were removed after 4, 7, 14 and 20 days for processing. On each sampling occasion, temperature, $\mathrm{pH}$, conductivity and dissolved oxygen were measured in the stream (WTW, Weilheim, Germany), and stream water samples were collected simultaneously and brought back to the laboratory for nutrient measurements according to French and international standards (NF T90-023, NF EN ISO 11732 and NF EN ISO 13395).

\section{Laboratory assays}

Diatoms sampled on glass slides immersed for 4 weeks in the Riou-Mort river (March 2006) were inoculated into freshwater microcosms (Gold et al., 2003; Morin et al., 2008b). Among the 66 species (representing 27 genera), the dominant taxa were Navicula lanceolata (Agardh) Ehrenberg (35.8\%), N. gregaria Donkin (11.1\%), Planothidium lanceolatum (Brébisson ex Kützing) Lange-Bertalot (9.3\%), Surirella brebissonii Krammer \& Lange-Bertalot $(5.2 \%)$ and a certain number of Gomphonema spp. (G. micropus Kützing, G. parvulum [Kützing] Kützing, G. olivaceum [Hornemann] Brébisson; 9.0\%) and Nitzschia spp. (N. dissipata [Kützing] Grunow, $N$. palea [Kützing)] W. Smith, N. linearis var. linearis [Agardh] W.M. Smith; 5.3\%).

In the experimental microcosms, the periphytic algae were allowed to grow on similar glass slides as those used in the field to maintain their benthic growth features and collected after a colonization duration of 1, 2, 4 and 6 weeks. The culture medium used for the experiment was a fourfold diluted WC medium (Guillard \& Lorenzen, 1972), without EDTA and supplemented with silica as proposed by Gold et al. (2003). This ensured nutrient (C, H, N, O, P, S) as well as trace element ( $\mathrm{Mn}, \mathrm{B}, \mathrm{Cu}, \mathrm{Fe}, \mathrm{Cl}, \mathrm{Co}, \mathrm{Mo}$, $\mathrm{Zn}$ ) and vitamin (thiamine, biotin, cobalamin) supply. Cultures were grown in triplicate and allowed to settle on the slides in the experimental units placed in an air-conditioned room where temperatures were kept constant, illuminated from above by fluorescent tubes (Claude Standard 18 W 10/54/154, Sylvania Lighting International, France) giving an average photon flux density of $70 \mu \mathrm{mol} \mathrm{s} \mathrm{s}^{-1} \mathrm{~m}^{-2}$ (Quantum sensor LI-COR LI-192SA, Lincoln, NE, USA) with a 10:14 light-dark cycle. The systems were under continuous water movement (approximate speed: $0.4 \mathrm{~cm} \mathrm{~s}^{-1}$ ), induced by the load difference between the height of the intermediate column feeding the systems and the three artificial streams.

At each sampling date, physical and chemical parameters in the microcosms were determined according to the procedures used for field assays. Depending on the results of water analyses, culture medium was added as required to compensate for the decrease of nutrient concentrations due to algal uptake.

Diatom counts and identification

Periphyton film was removed from the artificial substrates by scraping with a cutter blade and diluted to a standard volume of $100 \mathrm{ml}$ to form three replicate periphyton samples per site and per sampling date. Suspensions of the material were subsampled for various analyses. Diatom cell density was estimated for each replicate sample by counting the total number of cells exhibiting chloroplasts in 10 fields $(1.25 \mu \mathrm{l}$ each, $0.5 \mathrm{~mm}$ depth) of a Nageotte counting chamber, using light microscopy at $400 \times$ magnification (photomicroscope Leica DMRB, Wetzlar, Germany). Data were recorded as cells per unit area of sampled substrate (number of cells $\mathrm{cm}^{-2}$ ).

Aliquots assigned to taxonomic analysis of diatom assemblages were prepared according to the procedure described in ANSP protocols (Charles et al., 2002). After digestion of the formalin-fixed sample in boiling hydrogen peroxide $\left(30 \% \mathrm{H}_{2} \mathrm{O}_{2}\right)$ and hydrochloric acid (35\%), permanent slides were prepared by mounting the cleaned diatom frustules on a glass microscope slide in Naphrax ${ }^{\odot}$ (Brunel Microscopes Ltd, UK), a high refractive index (1.74) medium. At least 400 frustules were counted per replicate slide at $1,000 \times$ magnification and identified following the Sü $\beta$ wasserflora (Krammer \& Lange-Bertalot, 19861991) classification and recent nomenclature updates. Specific cell volumes were calculated using a set of 
geometric shapes and mathematical equations for biovolume calculations (Hillebrand et al., 1999) from literature linear dimensions.

Absolute abundances of each species, in individuals $\mathrm{cm}^{-2}$, were calculated after total diatom densities and relative abundances of each species identified during taxonomic determinations. These data also allowed the quantitative characterization of diatom communities in terms of biovolume, separating three classes of cell sizes (Morin et al., 2007), and evolution through the duration of the study.

Calculation of specific growth rates

For each experimental condition, growth rates $(k$, expressed as divisions day $^{-1}$ ) and generation-doubling-times $\left(t_{\mathrm{d}}\right)$ of the most abundant diatoms from the three replicates were calculated according to Guillard (1973). Growth rate differences between the diatoms collected over the two experiments were investigated among the species found in all the samples and representing at least $2 \%$ of the relative abundances.

The number of divisions per day was calculated from the slope of the linear portion of a curve showing $\log$ cell number as a function of time: $k=\frac{\ln (x 2)-\ln (x 1)}{d 2-d 1}$, where $x 1$ is the cell number at day $d 1$ (cell $\mathrm{cm}^{-2}$ ) and $x 2$ the cell number at day $d 2$ $\left(\right.$ cell $\mathrm{cm}^{-2}$ ). In this study, instead of the two countings needed, three or four dates (depending on the results obtained for $k$ ) were sampled during the exponential growth phase, and regression coefficients were calculated by regression analysis of the logarithm of the cell counts against the time in days, in order to increase the precision of the results. From $k$, generation times (in days) were computed by $t_{\mathrm{d}}=\frac{\ln (2)}{k}$.

Correlations between growth rate and cell sizes were analyzed using linear regressions (MS-Excel) performed on $\log _{10}$-transformed biovolume data. $T$ statistics were used to test the regression coefficient $\left(R^{2}\right)$ for significance, at the $0.01 \alpha$-level.

\section{Results}

Laboratory and field colonization conditions

The physical and chemical parameters measured in the water samples for both experiments are shown in Table 1.

$\mathrm{pH}(7.7 \pm 0.1)$ and oxygen saturation $(>75 \%)$ were very similar between treatments. The temperature imposed in the microcosms was quite stable $\left(18.8 \pm 0.0^{\circ} \mathrm{C}\right)$ but fluctuated in the field from 2.7 to $13.9^{\circ} \mathrm{C}$ during the experimental period. Lower nutrient concentrations were generally measured in the field but were still high enough not to be limiting for diatom development. The conductivities were very different between experiments. In laboratory microcosms, values were around $170 \mu \mathrm{S} \mathrm{cm} \mathrm{cm}^{-1}$; whereas mean values exceeding $2,000 \mu \mathrm{S} \mathrm{cm}^{-1}$ were recorded in the field study, indicating greater overall mineral content in the stream attributed to wastewater

Table 1 Summary of physical and chemical data of the water for the microcosm and field studies (SE: standard errors)

\begin{tabular}{|c|c|c|c|c|c|}
\hline \multirow[b]{2}{*}{$\mathrm{pH}$} & \multirow[b]{2}{*}{ Mean $\pm \mathrm{SE}$} & \multicolumn{2}{|c|}{ Laboratory experiment } & \multicolumn{2}{|c|}{ Field study } \\
\hline & & 7.6 & \pm 0.0 & 7.7 & \pm 0.1 \\
\hline Temperature $\left({ }^{\circ} \mathrm{C}\right)$ & Mean $\pm \mathrm{SE}$ & 18.8 & \pm 0.0 & 7.7 & \pm 2.2 \\
\hline Oxygen saturation (\%) & Mean $\pm \mathrm{SE}$ & 94.5 & \pm 0.5 & 76.5 & \pm 4.9 \\
\hline Conductivity $\left(\mu \mathrm{S} \mathrm{cm}^{-1}\right)$ & Mean \pm SE & 173.2 & \pm 2.8 & 2546.0 & \pm 533.1 \\
\hline Nitrate $\left(\mathrm{mg} \mathrm{l}^{-1}\right)$ & Mean $\pm \mathrm{SE}$ & 25.0 & \pm 1.9 & 4.8 & \pm 0.3 \\
\hline Nitrite $\left(\mathrm{mg} \mathrm{l}^{-1}\right)$ & Mean \pm SE & 0.8 & \pm 0.5 & 0.3 & \pm 0.1 \\
\hline Ammonium (mg $\left.{ }^{-1}\right)$ & Mean $\pm \mathrm{SE}$ & 0.1 & \pm 0.0 & 1.2 & \pm 0.3 \\
\hline Kjeldahl nitrogen $\left(\mathrm{mg} \mathrm{l}^{-1}\right)$ & Mean \pm SE & 5.9 & \pm 0.6 & 2.2 & \pm 0.1 \\
\hline Orthophosphate $\left(\mathrm{mg} \mathrm{l}^{-1}\right)$ & Mean $\pm \mathrm{SE}$ & 1.9 & \pm 0.3 & 0.3 & \pm 0.0 \\
\hline Irradiance $\left(\mu \mathrm{mol} \mathrm{m}{ }^{-2} \mathrm{~s}^{-1}\right)$ & Mean & 70 & & 640 & \\
\hline Water velocity $\left(\mathrm{cm} \mathrm{s}^{-1}\right)$ & Mean & 0.4 & & $\sim 1.5$ & \\
\hline
\end{tabular}

${ }^{a}$ In situ current velocity is given inside the caged samplers and, in brackets, that of the water surface 
treatment (e.g. $\mathrm{pH}$ adjustment) on the mining site (Audry et al., 2006). Light irradiance reaching the stream surface during the colonization periods was of about $640 \mu \mathrm{mol} \mathrm{m} \mathrm{m}^{-2} \mathrm{~s}^{-1}$ in the field in March 2005 and approximately $590 \mu \mathrm{mol} \mathrm{m}{ }^{-2} \mathrm{~s}^{-1}$ in March 2006 (http://www.meteofrance.com).

Growth experiments in indoor microcosms

Global qualitative characterization of diatom communities revealed very similar taxonomic composition between the diatoms inoculated in the microcosms and those sampled at week 1 in the experimental unit, with a Jaccard similarity index of 0.95 . Species richness in the systems was of 58 species representing 21 genera, but growth rates were assessed for the 13 main species (i.e. the species reaching a relative abundance $>2 \%$ in the communities considered). The communities were characterized by an association of Navicula gregaria (21.1\%), N. lanceolata (15.1\%), Nitzschia palea $(13.3 \%), N$. dissipata $(9.2 \%)$ and Surirella brebissonii $(6.8 \%)$ at week 1 , and then most of these species suffered a significant decrease $(P<0.05)$ in relative abundances, the communities being represented by higher amounts of Nitzschia palea (35.6\%) and Navicula(dicta) seminulum (Grunow) Lange Bertalot (33.6\%).

Most of the diatoms reached their exponential phase of growth in the first 3 weeks of the experiment. The specific growth rates (Table 2) ranged from 0.06 to $0.27 \mathrm{div}_{\mathrm{day}}{ }^{-1}$, and generation times were below 3 days for the fastest growing species (Navicula(dicta) seminulum) and increased to over 2 weeks for the species Surirella brebissonii. Specific growth rates were also strongly correlated to cell biovolume (Fig. $2 ; R^{2}=0.53, P<0.01$ ), expressing size dependence of the growth rates for the diatom species recorded.

The increase in total community biovolume $\left(1,800-45,500 \mu \mathrm{m}^{3}\right)$ calculated at each date was concomitant with an increase in the number of cells (Fig. 3). However, differences in the distribution of species sizes were noticed: small to medium species accounted for the greatest part of the community

Table 2 Individual biovolumes (in $\mu \mathrm{m}^{3}$ ) and growth characteristics ( $k$ in div day ${ }^{-1}, t_{\mathrm{d}}$ in days) for species common to both laboratory and field assays

\begin{tabular}{|c|c|c|c|c|c|c|c|}
\hline \multirow[t]{2}{*}{ Species } & \multirow[t]{2}{*}{ Biovolume } & \multicolumn{3}{|c|}{ Laboratory experiment } & \multicolumn{3}{|l|}{ Field study } \\
\hline & & Mean $k \pm \mathrm{SE}$ & Mean $t_{\mathrm{d}} \pm \mathrm{SE}$ & $R^{2}$ & Mean $k \pm \mathrm{SE}$ & Mean $t_{\mathrm{d}} \pm \mathrm{SE}$ & $R^{2}$ \\
\hline Navicula(dicta) seminulum & 69 & $0.27 \pm 0.01^{\mathrm{a}}$ & $2.57 \pm 0.10$ & 0.93 & & - & \\
\hline Eolimna minima & 88 & $0.17 \pm 0.03^{\mathrm{a}}$ & $4.38 \pm 0.74$ & 0.90 & & - & \\
\hline Craticula molestiformis & 119 & $0.12 \pm 0.00^{\mathrm{a}}$ & $5.97 \pm 0.14$ & 0.86 & & - & \\
\hline Nitzschia pusilla & 185 & $0.16 \pm 0.03^{\mathrm{a}}$ & $4.59 \pm 0.96$ & 0.77 & $0.32 \pm 0.04^{\mathrm{c}}$ & $2.21 \pm 0.31$ & 0.86 \\
\hline Planothidium frequentissimum & 219 & $0.09 \pm 0.02^{\mathrm{b}}$ & $8.00 \pm 1.37$ & 0.75 & $0.31 \pm 0.03^{\mathrm{b}}$ & $2.24 \pm 0.22$ & 0.98 \\
\hline Navicula veneta & 279 & $0.11 \pm 0.00^{\mathrm{a}}$ & $6.59 \pm 0.17$ & 0.71 & $0.35 \pm 0.09^{c}$ & $2.12 \pm 0.54$ & 0.94 \\
\hline Nitzschia acicularis & 289 & & - & & $0.41 \pm 0.06^{\mathrm{a}}$ & $1.74 \pm 0.27$ & 0.85 \\
\hline Gomphonema parvulum & 326 & $0.07 \pm 0.00^{\mathrm{b}}$ & $9.93 \pm 0.37$ & 0.73 & $0.41 \pm 0.04^{\mathrm{c}}$ & $1.71 \pm 0.18$ & 0.94 \\
\hline Nitzschia palea & 391 & $0.10 \pm 0.02^{\mathrm{b}}$ & $6.96 \pm 1.19$ & 0.81 & $0.33 \pm 0.02^{\mathrm{a}}$ & $2.14 \pm 0.14$ & 0.97 \\
\hline Planothidium lanceolatum & 475 & $0.11 \pm 0.00^{\mathrm{a}}$ & $6.39 \pm 0.12$ & 0.96 & $0.32 \pm 0.08^{\mathrm{c}}$ & $2.30 \pm 0.59$ & 0.88 \\
\hline Navicula gregaria & 485 & & - & & $0.33 \pm 0.02^{\mathrm{c}}$ & $2.14 \pm 0.14$ & 0.94 \\
\hline Nitzschia capitellata & 549 & $0.10 \pm 0.01^{\mathrm{a}}$ & $7.24 \pm 1.17$ & 0.85 & $0.34 \pm 0.02^{\mathrm{a}}$ & $2.02 \pm 0.10$ & 0.97 \\
\hline Nitzschia dissipata & 625 & $0.06 \pm 0.00^{\mathrm{a}}$ & $11.00 \pm 0.33$ & 0.85 & & - & \\
\hline Navicula lanceolata & 1,227 & & - & & $0.26 \pm 0.03^{\mathrm{b}}$ & $2.75 \pm 0.40$ & 0.84 \\
\hline Surirella angusta & 1,315 & $0.08 \pm 0.01^{\mathrm{b}}$ & $8.59 \pm 1.31$ & 0.81 & & - & \\
\hline Nitzschia linearis var. linearis & 1,624 & & - & & $0.30 \pm 0.01^{\mathrm{b}}$ & $2.31 \pm 0.11$ & 0.77 \\
\hline Nitzschia linearis var. tenuis & 1,785 & & - & & $0.36 \pm 0.16^{\mathrm{a}}$ & $2.80 \pm 1.61$ & 0.74 \\
\hline Surirella brebissonii & 2,654 & $0.06 \pm 0.03^{\mathrm{a}}$ & $15.51 \pm 8.89$ & 0.72 & $0.17 \pm 0.02^{\mathrm{b}}$ & $4.16 \pm 0.56$ & 0.66 \\
\hline Ulnaria ulna & 4,724 & & - & & $0.10 \pm 0.01^{\mathrm{b}}$ & $7.20 \pm 1.11$ & 0.85 \\
\hline
\end{tabular}

Calculations were based upon: ${ }^{a}$ the three-first dates, ${ }^{b}$ the four dates, ${ }^{c}$ the last three dates 


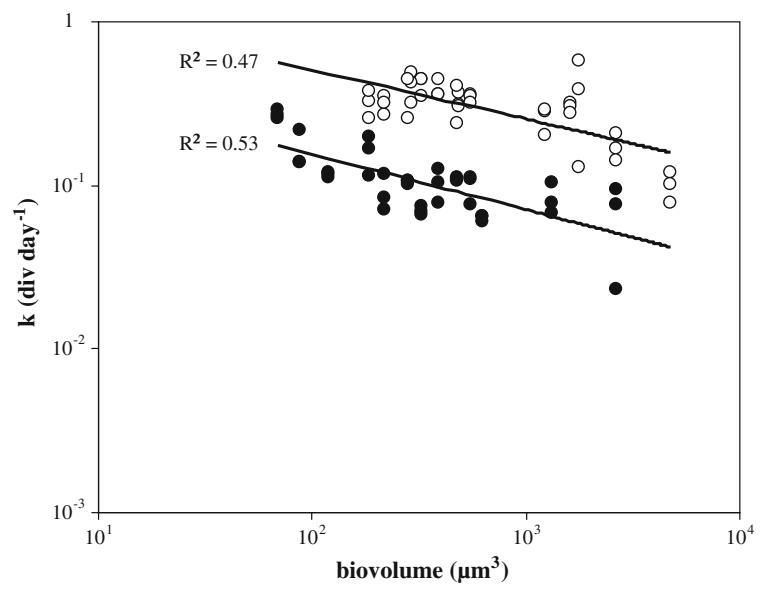

Fig. 2 Relationships between growth rate and cell biovolume (logarithmic sizes) of the diatoms inventoried in the laboratory $\left(\bullet, k=0.74 \mathrm{vOL}^{-0.34}\right)$ and field $\left(\bigcirc, \quad k=2.05 \mathrm{vOL}^{-0.31}\right)$ experiments

(from more than $60 \%$ to almost $95 \%$ ) in terms of cell numbers, but at least $75 \%$ of the total biovolume, of which medium-sized $\left(100-500 \mu \mathrm{m}^{3}\right)$ accounted for $65 \%$.

Growth experiments in field conditions

Altogether 106 species distributed over 38 genera were recorded in March 2005; however, only 14 taxa were found in relative abundances $>2 \%$ of the community and allowed growth rate calculations. In the first dates, diatom assemblages were dominated by Ulnaria ulna (Nitzsch) Lange-Bertalot (39.1\%), Nitzschia palea $(15.1 \%)$ and Navicula gregaria $(8.3 \%)$, and communities developed after 20 days were characterized by an association of Nitzschia palea (30.5\%), Navicula gregaria (16.7\%) Gomphonema parvulum (15.8\%), Nitzschia linearis var. linearis $(6.0 \%)$ and Ulnaria ulna $(5 \%)$.

Comparing the growth of the species from both sites showed a large spectrum of $k$ values varying from 0.10 (Ulnaria ulna) to $0.41 \mathrm{div} \mathrm{day}^{-1}$ (Gomphonema parvulum and Nitzschia acicularis (Kützing) W.M.Smith), that were significantly correlated with the logarithm of the cell size (Fig. 2; $\left.R^{2}=0.47 ; P<0.01\right)$.

As the number of cells increased (from 700 to almost 23,000 cells $\mathrm{cm}^{-2}$ ), total community biovolume followed the dynamics of biofilm growth, reaching $16,500 \mu^{3}$ on the last date (Fig. 3).
Although dominated by medium-sized diatoms, biomass accrual was greatly influenced by large $\left(>500 \mu \mathrm{m}^{3}\right)$ diatoms, representing $20 \%$ relative abundances and $60 \%$ of the total biomass at the end of the study.

Comparison of field growth rate data with laboratory measurements

Despite the fact that the indoor microcosms and field studies had been conducted in March of two different years, both experiments revealed comparable specific composition of diatom communities, with Jaccard similarity indices (performed on a dataset using the main species) between all the samples reaching at least $80 \%$.

Table 2 illustrates the variability in growth rates for experiments done in the field and in the laboratory: for a given species, field growth rates were twoto sixfold those found in controlled conditions, and the highest variations were recorded for Gomphonema parvulum and Nitzschia palea. Despite less controlled environmental conditions, the allometric relationship was quite as meaningful in field samples as in the laboratory experiments, growth rates significantly correlating with the logarithm of cell size (Fig. 2).

\section{Discussion}

Growth responses of several diatom species under artificial and natural conditions

Our experiments using natural communities grown under field and laboratory conditions revealed consistent responses of the periphytic communities; diatoms were predominant in all the biofilm samples, which is in accordance with the theory proposed by Tilman et al. (1986) that diatoms have high resource competitive ability at low water temperatures. The main species recorded are often predominant in the nutrient-impacted benthic algal assemblages found in the study region (Gold et al., 2002; Tison et al., 2005), and moreover, many of them are fairly common in winter (Eulin \& Le Cohu, 1998). According to generally accepted knowledge concerning species tolerance and sensitivity to pollution (van Dam et al., 1994), dominant diatoms were $\alpha$ meso- to 

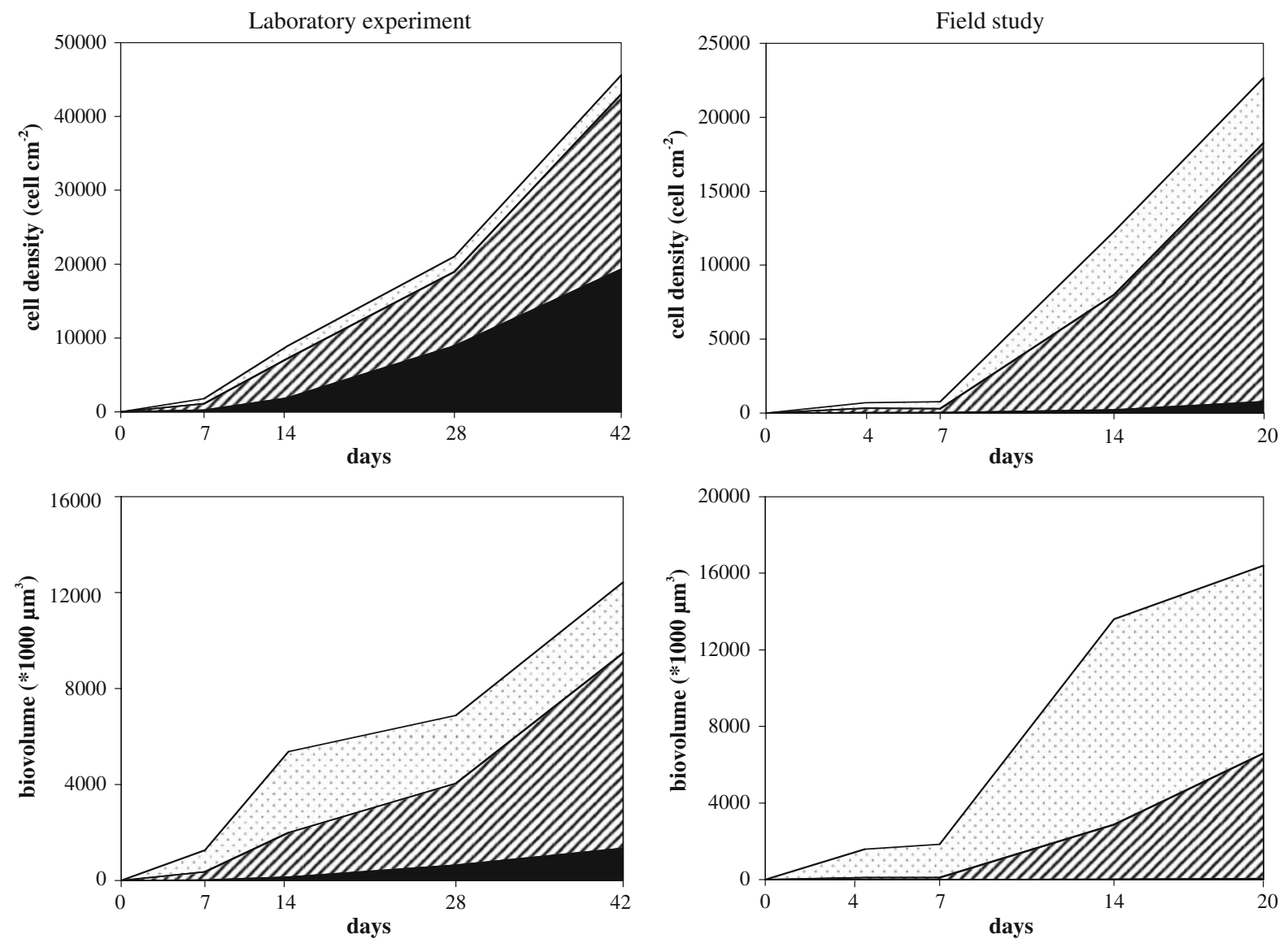

Fig. 3 Cell densities of small species (less than $100 \mu \mathrm{m}^{3}$, in black), medium species $\left(100-500 \mu \mathrm{m}^{3}\right.$, crosshatched) and large species (more than $500 \mu \mathrm{m}^{3}$, in white with black points), and their contribution to the total biovolume of the community

polysaprobic species usually found in eutrophic to hypereutrophic environments. The persistence of diatoms in disturbed environments has been widely documented (for a review, see Peterson, 1996), due to small cell size and rapid immigration/growth which were also observed in this study through the dates used for $k$ calculations. A literature survey of kinetic data for varied diatom species showed that the growth responses of the 19 diatom species studied [in both field (0.10-0.41 div day $\left.{ }^{-1}\right)$ and laboratory (0.06$\left.0.27 \mathrm{div} \mathrm{day}^{-1}\right)$ ] were somewhat lower than growth rates established in unialgal cultures of diatoms (Kilham, 1975; Tilman \& Kilham, 1976; Baars, 1983; Suzuki \& Takahashi, 1995) or the values provided in several studies using various taxonomic groups (Tang, 1995). Indeed, the scaling of sizedependant growth rates has been shown to differ among taxonomic groups in phytoplankton (Banse,
1982) or among growth forms (Nielsen, 2006). As mentioned in the above allometric studies, the highest growth rates throughout both experiments were still lower for diatom species with larger cell sizes.

Dominance or co-dominance of small to medium species was observed throughout the duration of both studies; however, their contributions to the total biovolume (and hence, total biomass) of the community, in particular in the latest stages of biofilm development, were drastically reduced: in field samples after a 20-day colonization, species having higher biovolumes $\left(>500 \mu^{3}\right)$ represented $20 \%$ relative abundances but $60 \%$ of the total biovolume (Fig. 3). Patterns in the size structure of phytoplankton communities have been shown to reflect seasonal variations, resource availability or perturbations (Kamenir et al., 2007; Naselli-Flores et al., 2007; Salmaso \& Padisák, 2007). Although the calculation 
of diatom community biovolumes may be too timeconsuming for routine biomonitoring purposes (Lavoie et al., 2006), Cattaneo et al. (1997) demonstrated a significant relationship between size distribution of periphytic assemblages and trophic status of the streams. Since large species are usually found at low abundances in benthic diatom communities, typology works often focus on these underrepresented species and manage to overweight them using log-transformed abundance values (ter Braak \& Verdonschot, 1995; Griffith et al., 2002; Tison et al., 2005). It has been underlined that these taxa have a high ecological significance (Snoeijs et al., 2002), and here, we show that their importance is also noticeable through the part they hold in the biovolume of the community. These observations thus confirm the ecological relevance of the use of $\log$ transformation of periphytic diatom relative abundance for the assessment of ecological conditions of stream water. This transformation also increases the accuracy of biotypologies (Tison et al., 2005; Park et al., 2006).

\section{Hypothesized life history strategies}

The relative abundances of small, medium and large species over time (Fig. 3) reflect the process of algal community development, and quantification of the community was quite different when considering cell numbers or total biovolume for each size. The $C-S-R$ selection strategies (Grime, 1977) are perhaps too general to account for most possible responses to different combinations of stresses and disturbances; however, based upon $k$ calculations and growth curves of the 19 species used in this study, a matrix defined by disturbance and stress can be drawn (Fig. 4). In the present study, disturbance frequency is quantified in physical terms (as recommended by Poff, 1992) and assessed through the immersion of blank substrates in the water. Stress here does not refer to nutrient supply, which is not a growth-limiting parameter here, but rather to canopy inducing light competition.

The $R$ (ruderal) selected taxa group incorporates early colonists of denuded or unstable habitats or opportunistic species (Hoagland et al., 1982). These small solitary Naviculaceae and Nitzschiaceae, loosely attached to the substrate (Kelly et al., 2005), are reported to be highly motile (Hudon \& Legendre, 1987; Tuji, 2000; Kelly et al., 2005), which enhances their immigration rates. Moreover, these cells have rapid growth characteristics (see Table 2) and generally high disturbance resistance. Once established as dominant in the earliest stages of biofilm development, those species that are attached to the substrate may form algal mats favouring the implantation of many stalked and filamentous species that are favoured by high nutrient supply (Burkholder et al., 1990). Although their resistance to a wide range of disturbance or stress enables them to persist within mats of $C$ or $S$ selected taxa during the latest stages of biofilm development, these species are little represented in "peak biomass" communities grown under non-limiting nutrient supply, due to species replacement (by $C$ or $S$ selected species) and to their small size little influencing total biovolume (see Fig. 3).
Fig. 4 Hypothesized $C-S$ $R$ grouping from growth characteristics determined in this study

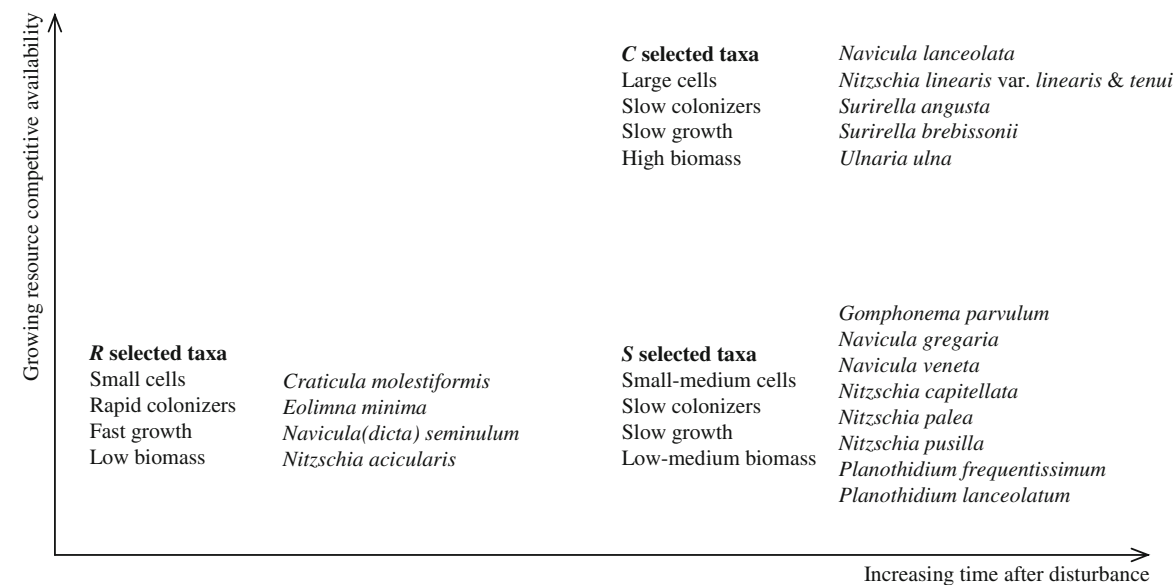

Increasing time after disturbance 
Taxa of the $S$ (stress tolerant) selection group are slower colonizers adapted to succeed in stressed habitats. Many of the group are saprophilous species (van Dam et al., 1994); they appear to have intermediate growth rates, between the fast rates of $R$ selected taxa and the slow rates of the $C$ selected taxa, and their abundances (varying between $40 \%$ and $70 \%$ relative abundances in the field experiment) are only slightly influenced by successional development of the biofilm. Most taxa within this group have small- to medium-sized cells with various holdfast mechanisms ranging from simple prostrate adhesion (Planothidium sp.; Cox 1996) to stalked structures (Gomphonema parvulum; Cox 1996) sometimes forming ramified arborescent associations (Hudon \& Legendre, 1987) or small rosettes (Hoagland et al., 1982). Together with the large $C$ selected taxa, these low-profile diatoms form thickened mats of prostrate, stalked and filamentous cells embedded in mucilage, an assembly that contributes to community development entrapping other algae and serving as a mechanism for attachment to the substrate.

In this study, almost none of the $C$ (competitive) selected taxa were numerous at the first dates of sampling. These large, mid-late successional species, which probably utilize the mat of species firmly attached to the substratum to settle, are then highly competitive with abundant nutrient supply (Stevenson et al., 1991; Biggs et al., 1998). Traits enabling dominance of $C$ selected species are related to large cell size and to attachment features: stalked or short filamentous structures (Ulnaria ulna; Biggs et al. 1998) mixed with mucilage-forming diatoms (Navicula and Nitzschia spp.; Hoagland et al. 1982; Biggs et al. 1998). Some stellate colonies of diatoms such as Ulnaria sp. have been reported to have the ability to attach not only to the substrates, but also to diatom stalks (Hoagland et al., 1982; Roemer et al., 1984). This would imply that these rosette-forming diatoms would create tall structures that overtop basal-layer pioneer taxa (i.e. $R$ selected) and thus have an advantage over other vertically positioned diatoms in competition for space, and hence resources (light and nutrients). This way, they may also limit or even suppress the growth of other populations. These coherent mucilaginous communities could also enable fixation of non-attached (floating or freely motile) cells like Surirella sp. or Navicula lanceolata (Kelly et al., 2005).
Representativeness of microcosm experiments

Ideally, the experimental systems should be as similar as possible to the environment they will be compared to. Although our microcosm experiments were supposed to mimic the field conditions we observed in March 2005, some technical limitations restricted the harmonization of certain environmental parameters (increasing temperatures, conductivity, irradiance). Moreover, our results indicate that many "uncontrolled" field factors still interact and affect the $k$ and $t_{\mathrm{d}}$ values of the 13 diatoms studied. It would have been expected that the communities in the field would not be especially fast-growing in comparison to laboratory cultures. However, among the species we studied, most grew better in situ than in microcosms, which appears to be in conflict with Kagami and Urabe (2001), who found lower growth rates, for a given cell size, in field experiments than in laboratory cultures. The exponents of the power function for field (0.31) and laboratory (0.34) data were higher than the ranges of values estimated by Tang (1995). This however suggests that the slopes and determination coefficients could be comparable between field and laboratory experiments, when using a similar species inoculum. The growth rates of algal species would thus not exclusively be determined by cell size, but also by specific "culture" conditions and by the algal classes considered (data from the literature take into account various microalgal groups).

The differences in growth rates for a given species observed between laboratory and field results would be explained by various determinants alone or in interaction, which were unclearly identified in this study but are likely to be species-specific. The relationship between growth characteristics of algae and resource (N, P, Si) competitive ability have been described by a number of authors (Kilham, 1975; Tilman et al., 1981; Tilman, 1990; van Donk \& Kilham, 1990), and although it is obviously not the only parameter involved, nutrient supply was quite different between field (continuous inputs) and laboratory (sporadic additions of culture medium to compensate nutrient depletion) conditions. Under these nutrient-unlimited conditions, the impact of many physical parameters is not to be neglected. Indeed, most of the diatom species used for the calculation of growth constants are able to develop over a wide range of conductivities, as shown in 
Europe by van Dam et al. (1994) and in US rivers by Potapova and Charles (2003). Concerning the species that developed in the artificial streams but were not found in the field, it can be argued that their growth abilities would have been altered by the one order magnitude difference in conductivities with the natural waters; some of them (like Navicula(dicta) seminulum, Eolimna minima, Ulnaria ulna) are described to display a rather limited range of conductivity affinities (Potapova \& Charles, 2003). However, the species Eolimna minima and Ulnaria ulna have been found in considerable amounts in summer at Decazeville (Morin et al., 2007), suggesting that temperature and light irradiance may be more important factors. The diatoms recorded here were cold-water species or taxa able to withstand cold water; however, differences in temperature regimes (i.e. stable temperatures versus daily and seasonal fluctuations) probably affected diatom settlement and species growth responses (Patrick, 1977; Montagnes \& Franklin, 2001). It has been demonstrated by Nicklisch (1998) that natural fluctuation in light intensity (increases/decreases in light irradiances due to the regular course of sunlight, to clouding, etc.) is a determining factor influencing diatom growth rates, generally interacting with temperature (Baars, 1983; El-Sabaawi \& Harrison, 2006). The light levels imposed in the laboratory microcosms were approximately 10 -fold lower than natural saturating light levels in this area; however, the real difference between light conditions is probably smaller than appears from measurements because neither refraction nor attenuation occurred between surface and the 10-cm depth (Padisák, 2005) where the slides were exposed. We assumed that photoacclimation of the diatoms in response to changes between field and laboratory conditions occurred on a short time scale and we did not apply any preincubation period even though there was a decrease in light irradiance of the new environment. However, Falkowski and LaRoche (1991) describe that the process necessitates about one cell's generation; with regards to the generation times found in the laboratory experiment (15 days for the slowest growing species), the shift from higher to lower irradiance may have seriously delayed growth kinetics, depending on the species' photoacclimation strategies. Flow velocity is also known to significantly condition the structure of the community; Ghosh and Gaur (1998) described a stimulatory effect of intermediate current velocities on the growth of many species, which may also partly explain the differences in cell densities between laboratory and field studies. Finally, biological factors may be involved too. We assumed that sloughing, grazing activities or the establishment of other periphytic algae, which were not observed in either of the treatments, were not here significantly to the detriment of diatoms. However, field biofilms may have benefited from continuous inputs of diatoms from the upstream pool. As demonstrated by Stevenson and Peterson (1991), immigration rates have a major impact on diatom community settlement and development. Indeed, the total number of species recorded in the field study was twice as high as in the laboratory experiment, for a comparable counting effort. It can be hypothesized that some species, although they were present in the inoculum (e.g. Navicula lanceolata-35.8\% relative abundances in the sample inoculated-or $N$. gregaria-11.1\%), were slow colonizers that did not find suitable conditions for settlement at the beginning of the microcosm experiment, and thus were not able to grow afterwards and did not survive. However, Stevenson and Peterson (1989) also demonstrated that immigration rates are species-specific and vary among habitats but, for a given site, are quite constant in time. Hence continuous immigration would not have a marked effect on diatom growth constants calculated in the exponential phase.

Growing interest is being devoted to laboratorybased experiments, since in nature attached communities are often difficult to investigate (McCormick \& Cairns, 1994). Unlike a study of Roeselers et al. (2006) that demonstrated poor reproducibility of microcosm experiments in terms of species richness and community composition, the present experiment displayed low variability between replicates. The conditions within the experimental units, however, did not exactly resemble environmental conditions, which affected diatom growth kinetics as discussed above. While the nutrient levels were certainly adequate to saturate specific cellular growth rates of diatoms, they were not sufficient to saturate sustainable biomass (as discussed by Bothwell, 1989). Environmental parameters probably set $k$ for the species studied; indeed, light and temperature conditions may explain the two- to sixfold lower growth in the laboratory. Despite this physical limitation of $k$, it 
is worthy to underline that allometric relationships were still intact.

Acknowledgements The authors are grateful to M. Bonnet, M. Boudigues, H. Bouillard, V. Duflo and T. T. Duong for their precious help during both experiments. This article benefitted from the critical comments of the referees.

\section{References}

Admiraal, W., C. Barranguet, S. A. M. van Beusekom, E. A. J. Bleeker, F. P. van den Ende, H. G. van der Geest, D. Groenendijk, N. Ivorra, M. H. S. Kraak \& S. C. Stuijfzand, 2000. Linking ecological and ecotoxicological techniques to support river rehabilitation. Chemosphere 41: 289-295.

Audry, S., G. Blanc \& J. Schäfer, 2006. Solid state partitioning of trace metals in suspended particulate matter from a river system affected by smelting-waste drainage. Science of the Total Environment 363: 216-236.

Baars, J. W., 1983. Autoecological investigations on freshwater diatoms. 1. Generation times of some species. Archiv für Hydrobiologie-Supplement 67: 11-18.

Banse, K., 1982. Cell volumes, maximal growth rates of unicellular algae and ciliates, and the role of ciliates in marine pelagial. Limnology and Oceanography 27: 10591071 .

Biggs, B. J. F., 1990. Use of relative specific growth rates of periphytic diatoms to assess enrichment of a stream. New Zealand Journal of Marine and Freshwater Research 24: 9-18.

Biggs, B. J. F., R. J. Stevenson \& R. L. Lowe, 1998. A habitat matrix conceptual model for stream periphyton. Archiv für Hydrobiologie 143: 21-56.

Bothwell, M. L., 1985. Phosphorus limitation of lotic periphyton growth rates: An intersite comparison using continuous-flow troughs (Thompson River system, British Columbia). Limnology and Oceanography 30: 527-542.

Bothwell, M. L., 1989. Phosphorus-limited growth dynamics of lotic periphytic diatom communities: Areal biomass and cellular growth rate responses. Canadian Journal of Fisheries and Aquatic Sciences 46: 1293-1301.

Burkholder, J. M., R. G. Wetzel \& K. L. Klomparens, 1990. Direct comparison of phosphate uptake by adnate and loosely attached microalgae within an intact biofilm matrix. Applied and Environmental Microbiology 56: 2882-2890.

Cattaneo, A., T. Kerimian, M. Roberge \& J. Marty, 1997. Periphyton distribution and abundance on substrata of different size along a gradient of stream trophy. Hydrobiologia 354: 101-110.

Charles, D. F., C. Knowles \& R. S. Davies, 2002. Protocols for the analysis of algal samples collected as part of the U.S. Geological Survey National Water-Quality Assessment Program. Patrick Center for Environmental Research, The Academy of Natural Sciences, Philadelphia, PA.

Conway, H. L. \& S. C. Williams, 1979. Sorption of cadmium and its effects on growth and the utilization of inorganic carbon and phosphorus of two freshwater diatoms. Journal of Fisheries Research Board of Canada 36: 579-586.

Cox, E. J., 1996. Identification of freshwater diatoms from live material. Chapman \& Hall, London, UK.

Descamps-Julien, B. \& A. Gonzalez, 2005. Stable coexistence in a fluctuating environment: An experimental demonstration. Ecology 86: 2815-2824.

El-Sabaawi, R. \& P. J. Harrison, 2006. Interactive effects of irradiance and temperature on the photosynthetic physiology of the pennate diatom Pseudo-nitzschia granii (Bacillariophyceae) from the northeast subarctic Pacific. Journal of Phycology 42: 778-785.

Eulin, A. \& R. Le Cohu, 1998. Epilithic diatom communities during the colonization of artificial substrates in the River Garonne (France). Comparison with the natural communities. Archiv für Hydrobiologie 143: 79-106.

Falkowski, P. G. \& J. LaRoche, 1991. Acclimation to spectral irradiance in algae. Journal of Phycology 27: 8-14.

Ghosh, M. \& J. P. Gaur, 1998. Current velocity and the establishment of stream algal periphyton communities. Aquatic Botany 60: 1-10.

Gold, C., A. Feurtet-Mazel, M. Coste \& A. Boudou, 2002. Field transfer of periphytic diatom communities to assess short-term structural effects of metals $(\mathrm{Cd}, \mathrm{Zn})$ in rivers. Water Research 36: 3654-3664.

Gold, C., A. Feurtet-Mazel, M. Coste \& A. Boudou, 2003. Effects of cadmium stress on periphytic diatom communities in indoor artificial streams. Freshwater Biology 48: 316-328.

Goldman, J. C., 1980. Physiological processes, nutrient availability and the concept of relative growth rate in marine phytoplankton ecology. In Falkowski, P. G. (ed.), Primary Productivity in the Sea. Plenum, New York: 179-194.

Griffith, M. B., B. H. Hill, A. T. Herlihy \& P. R. Kaufmann, 2002. Multivariate analysis of periphyton assemblages in relation to environmental gradients in Colorado rocky mountain streams. Journal of Phycology 38: 83-95.

Grime, J. P., 1977. Evidence for the existence of three primary strategies in plants and its relevance to ecological and evolutionary theory. The American Naturalist 111: 11691194.

Guillard, R. R. L., 1973. Division rates. In Stein, J. R. (ed.), Culture Methods and Growth Measurements. Handbook of Phycological Methods. Cambridge University Press, Cambridge: 289-311.

Guillard, R. R. L. \& C. J. Lorenzen, 1972. Yellow-green algae with chlorophyllide $c$. Journal of Phycology 8: 10-14.

Hillebrand, H., C. D. Dürselen, D. Kirschtel, U. Pollingher \& T. Zohary, 1999. Biovolume calculation for pelagic and benthic microalgae. Journal of Phycology 35: 403-424.

Hoagland, K. D., S. C. Roemer \& J. R. Rosowski, 1982. Colonization and community structure of two periphyton assemblages, with emphasis on the diatoms (Bacillariophyceae). American Journal of Botany 69: 188-213.

Hudon, C. \& P. Legendre, 1987. The ecological implications of growth forms in epibenthic diatoms. Journal of Phycology 23: 434-441.

Kagami, M. \& J. Urabe, 2001. Phytoplankton growth rate as a function of cell size: an experimental test in Lake Biwa. Limnology 2: 111-117. 
Kamenir, Y., Z. Dubinsky, A. Alster \& T. Zohary, 2007. Stable patterns in size structure of a phytoplankton species of Lake Kinneret. Hydrobiologia 578: 79-86.

Kelly, M. G., H. Bennion, E. J. Cox, B. Goldsmith, J. Jamieson, S. Juggins, D. G. Mann \& R. J. Telford, 2005. Common freshwater diatoms of Britain and Ireland: An interactive key. Environment Agency, Bristol.

Kilham, S. S., 1975. Kinetics of silicon-limited growth in the freshwater diatom Asterionella formosa. Journal of Phycology 11: 396-399.

Krammer, K. \& H. Lange-Bertalot, 1986-1991. Bacillariophyceae: 1 Teil: Naviculaceae; 2 Teil: Bacillariaceae, Epithemiaceae, Surirellaceae; 3 Teil: Centrales, Fragilariaceae, Eunotiaceae; 4 Teil: Achnanthaceae. Kritische Ergänzungen zu Navicula (Lineolatae) und Gomphonema. G. Fischer Verlag, Stuttgart.

Lange-Bertalot, H., 1979. Pollution tolerance of diatoms as a criterion for water quality estimation. Nova Hedwigia 64: 285-304.

Lavoie, I., S. Campeau, M. A. Fallu \& P. J. Dillon, 2006. Diatoms and biomonitoring: should cell size be accounted for? Hydrobiologia 573: 1-16.

McCormick, P. V. \& J. Cairns, 1994. Algae as indicators of environmental change. Journal of Applied Phycology 6: 509-526.

Montagnes, D. J. S. \& D. J. Franklin, 2001. Effect of temperature on diatom volume, growth rate, and carbon and nitrogen content: Reconsidering some paradigms. Limnology and Oceanography 46: 2008-2018.

Morin, S., T. T. Duong, A. Dabrin, A. Coynel, O. Herlory, M. Baudrimont, F. Delmas, G. Durrieu, J. Schäfer, P. Winterton, G. Blanc, A. Boudou \& M. Coste, 2008a. Long term survey of heavy metal pollution, biofilm contamination and diatom community structure in the Riou-Mort watershed, South West France. Environmental Pollution 151: 532-542.

Morin, S., T. T. Duong, O. Herlory, A. Feurtet-Mazel \& M. Coste, 2008b. Cadmium toxicity and bioaccumulation in freshwater biofilms. Archives of Environmental Contamination and Toxicology 54: 173-186.

Morin, S., M. Vivas-Nogues, T. T. Duong, A. Boudou, M. Coste \& F. Delmas, 2007. Dynamics of benthic diatom colonization in a cadmium/zinc-polluted river (RiouMort, France). Fundamental and Applied Limnology/Archiv für Hydrobiologie 168: 179-187.

Naselli-Flores, L., J. Padisák \& M. Albay, 2007. Shape and size in phytoplankton ecology: Do they matter? Hydrobiologia 578: 157-161.

Nicklisch, A., 1998. Growth and light absorption of some planktonic cyanobacteria, diatoms and Chlorophyceae under simulated natural light fluctuations. Journal of Plankton Research 20: 105-119.

Nielsen, S. L., 2006. Size-dependant growth rates in eukaryotic and prokaryotic algae exemplified by green algae and cyanobacteria: Comparisons between unicells and colonial growth forms. Journal of Plankton Research 28: 489-498.

Padisák, J., 2005. Általános Limnológia (General Limnology). ELTE Eötvös Kiadó, Budapest.

Park, Y. S., J. Tison, S. Lek, J. L. Giraudel, M. Coste \& F. Delmas, 2006. Application of a self organizing map to select representative species in multivariate analysis: A case study determining diatom distribution patterns across France. Ecological Informatics 1: 247-257.

Patrick, R., 1977. Ecology of freshwater diatoms and diatom communities. In Werner, D. (ed.), The Biology of Diatoms. Botanical Monographs 13, Oxford: 284-332.

Peterson, C. G., 1996. Response of benthic algal communities to natural physical disturbance. In Stevenson, R. J., M. L. Bothwell \& R. L. Lowe (eds), Algal Ecology: Freshwater Benthic Ecosystems. Academic Press, San Diego: 375-402.

Poff, N. L., 1992. Why disturbances can be predictable: A perspective on the definition of disturbance in streams. Journal of the North American Benthological Society 11: 86-92.

Potapova, M. \& D. F. Charles, 2003. Distribution of benthic diatoms in U. S. Rivers in relation to conductivity and ionic composition. Freshwater Biology 48: 1311-1328.

Roemer, S. C., K. D. Hoagland \& J. R. Rosowski, 1984. Development of a freshwater periphyton community as influenced by diatom mucilages. Canadian Journal of Botany 62: 1799-1813.

Roeselers, G., B. Zippel, M. Staal, M. van Loosdrecht \& G. Muyzer, 2006. On the reproducibility of microcosm experiments-Different community composition in parallel phototrophic biofilm microcosms. FEMS Microbiology Ecology 58: 169-178.

Salmaso, N. \& J. Padisák, 2007. Morpho-functional groups and phytoplankton development in two deep lakes (Lake Garda, Italy and Lake Stechlin, Germany). Hydrobiologia 578: 97-112.

Schmitt-Jansen, M. \& R. Altenburger, 2005. Toxic effects of isoproturon on periphyton communities-A microcosm study. Estuarine Coastal and Shelf Science 62: 539-545.

Snoeijs, P., S. Busse \& M. Potapova, 2002. The importance of diatom cell size in community analysis. Journal of Phycology 38: 265-281.

Steinberg, C. \& S. Schiefele, 1988. Biological indication of trophy and pollution of running waters. Zeitschrift für Wasser und Abwasser Forschung-Journal for Water and Wastewater Research 21: 227-234.

Stevenson, R. J. \& C. G. Peterson, 1989. Variation in benthic diatom (Bacillariophyceae) immigration with habitat characteristics and cell morphology. Journal of Phycology 25: 120-129.

Stevenson, R. J. \& C. G. Peterson, 1991. Emigration and immigration can be important determinants of benthic diatom assemblages in streams. Freshwater Biology 26: 279-294.

Stevenson, R. J., C. G. Peterson, D. B. Kirschtel, C. C. King \& N. C. Tuchman, 1991. Density-dependent growth, ecological strategies and effects of nutrients and shading on benthic diatom succession in streams. Journal of Phycology 27: 59-69.

Suzuki, Y. \& M. Takahashi, 1995. Growth responses of several diatom species isolated from various environments to temperature. Journal of Phycology 31: 880-888.

Tang, E. P. Y., 1995. The allometry of algal growth rates. Journal of Plankton Research 17: 1325-1335.

ter Braak, C. J. F. \& P. F. M. Verdonschot, 1995. Canonical correspondence analysis and related multivariate methods in aquatic ecology. Aquatic Sciences 57: 255-289. 
Tilman, D., 1977. Resource competition between planktonic algae: An experimental and theoretical approach. Ecology 58: $338-348$.

Tilman, D., 1990. Mechanisms of plant competition for nutrients: the elements of a predictive theory of competition. In Grace, J. \& D. Tilman (eds), Perspectives on Plant Competition. Academic Press, New York: 117-141.

Tilman, D., R. Kiesling, R. Sterner, S. S. Kilham \& F. A. Johnson, 1986. Green, bluegreen and diatom algae: taxonomic differences in competitive ability for phosphorus, silicon and nitrogen. Archiv für Hydrobiologie 106: 473-485.

Tilman, D. \& S. S. Kilham, 1976. Phosphate and silicate growth and uptake kinetics of the diatoms Asterionella formosa and Cyclotella meneghiniana in batch and semicontinuous culture. Journal of Phycology 12: 375-383.

Tilman, D., M. Mattson \& S. Langer, 1981. Competition and nutrient kinetics along a temperature gradient: An experimental test of a mechanistic approach to niche theory. Limnology and Oceanography 26: 1020-1033.
Tison, J., Y. S. Park, M. Coste, J. G. Wasson, L. Ector, F. Rimet \& F. Delmas, 2005. Typology of diatom communities and the influence of hydro-ecoregions: A study on the French hydrosystem scale. Water Research 39: 3177-3188.

Tuji, A., 2000. Observation of developmental processes in loosely attached diatom (Bacillariophyceae) communities. Phycological Research 48: 75-84.

van Dam, H., A. Mertens \& J. Sinkeldam, 1994. A coded checklist and ecological indicator values of freshwater diatoms from the Netherlands. Netherlands Journal of Aquatic Ecology 28: 117-133.

van Donk, E. \& S. S. Kilham, 1990. Temperature effects on silicon- and phosphorous-limited growth and competitive interactions among three diatoms. Journal of Phycology 26: 40-50.

Wood, A. M. \& T. Leatham, 1992. The species concept in phytoplankton ecology. Journal of Phycology 28: 723-729. 